\title{
Surfaces
}

\section{Feminism, Aging and Changing Paradigms}

\section{Roundtable 3}

\section{E. Ann Kaplan}

Volume 7, 1997

\section{LE FÉMINISME HORS DE LUI-MÊME}

FEMINISM BESIDE ITSELF

URI : https://id.erudit.org/iderudit/1064809ar

DOI : https://doi.org/10.7202/1064809ar

Aller au sommaire du numéro

Éditeur(s)

Les Presses de l’Université de Montréal

ISSN

1188-2492 (imprimé)

1200-5320 (numérique)

Découvrir la revue

Citer cet article

Kaplan, E. A. (1997). Feminism, Aging and Changing Paradigms: Roundtable 3. Surfaces, 7. https://doi.org/10.7202/1064809ar d'utilisation que vous pouvez consulter en ligne. 


\section{Feminism, Aging and Changing Paradigms Roundtable 3}

E. Ann Kaplan

SUNY Stony Brook

Surfaces Vol. VII.110 (v.1.0A - 27/06/1997) - ISSN:

1188-2492

Copyright for texts published in Surfaces remains the property of authors. However, any further publication should be accompanied by an acknowledgement of Surfaces as the place of initial publication.

\section{Part I: Performativity}

All perspectives are limited, constrained by what one cannot see and structured by context. One structuring context for the feminist standpoint I will outline is that of age. I use the word age rather than the more usual generation because it clarifies what is at stake and may avoid some of the problems that the word "generation" causes: Age refers to the personal/longitudinal axis as opposed to the loose cultural/historical subjectinterpellation that generation connotes (see my "map"). Age (on the longitudinal axis) means that one has been around for a while; that one has had certain experiences, participated in certain movements, perhaps even helped produce certain social and intellectual changes within a specific historical span of time. The having-done-thisness (by which I mean the having gone through such experiences) emerges as a special quality of aging. 
MAPPING FEMINISMS AND THE WORLD ORDER A PERFORMANCE PIECE OR PERFORMING AGE, GENERATION, NARRATIVE

\section{AXIS \\ 1. CAPITALISM V \\ SOCIALISM \\ BINARY}

AGE: PERSONAL GENERATION: / LONGITUDINAL CULTURAL

2. POSTCOLONIALITY women; growth

SOCIAL / TECHNICAL / POLITICAL Institutions, Processes

INTELLECTUAL 2.

1. MODERNISM (high/low culture binary)

3.

TRANSNATIONAL FINANCE CORPORATIONS

/ CULTURAL MOVEMENTS

\section{POSTMODERNISM}

(Pop/high culture Divide broached)

$$
\begin{aligned}
& \text { 3. CYBERAGE } \\
& \text { (simulation/ } \\
& \text { simulacra) }
\end{aligned}
$$

\section{HISTORICAL AXIS}

1. 60's - 70's

FEMINISMS attn.

white women

2. 80's - 90's

FEMINISMS

contesting 1 st wave debates white/black

non-white

feminisms; politics

of ethnic identity

3.

DECONSTRUCTING GENDER /

QUEERING

THEORY /

INTERNATIONAL

FEMINISMS

The "market;"

consumerism

1. FEMALE

IDENTITY

POLITICS: "white woman" as category

2. COMPLEX RACE/ GENDER IDENTITIES

3. DESTABALIZING IDENTITIES:

Virtual realities, internet subjectivities, new gender / race / performance / performativity 
While I would not claim that any of us are culturally fixed by any generational location, I would claim that such historical passing-throughs that we call "aging" make a difference in the questions we think to ask, in the conceptualizing of problems. For those who are aging, the series of experiences accumulates. One has memories; one has stories. One has narrativized the past (there is enough past to narrativize), which is far from saying that such narratives are "true." The stories have been made through the telling, which is why I have titled this section "Performativity," and the "map" that accompanies it "A Performance Piece." The stories are formed through the blindnesses and forgettings that characterize memory (as all the new psychological research tells us). Such narratives are limited and constrained by the specificities of the events one was part of-as against the plethora of other events that went on alongside the ones participated in. This means that generalization of the past, of what one experienced, is also impossible. As Judith Roof warns us at the conclusion of her essay in Feminism Beside Itself, we must "understand history as containing no truth, no knowledge, no enlightenment..." (Elam/Weigman, 1995:68). She asks that we narrate feminism not as a family affair, not through the motherhood paradigm (which Roof claims the term "generation" evokes) but "as a partial story with no beginning and no end and no structuring binaries" (p.68).

This theoretical position partly accords with my own, as evident in naming my totalizing "map" a performance. Yet I allow my performance piece to include beginnings and binaries because intellectual understanding can only take place through positing and then debating, even discarding, such binaries. In order for Roof to make her claim, she has to express it by negating the binaries of beginning and ending, and by noting how binaries are structuring. Implicitly, then, Roof relies on prior binary thinking to locate her position much as I do .

\section{Performing Intellectual Feminist Paradigms}

To provide a context for what follows, I will first narrativize the broad intellectual paradigms that my stretch of feminism has involved-paradigms that do not rely on that of motherhood, which Roof claims dominates feminist herstories. Feminism was originally a modernist movement. Indeed, 60s-80s feminisms arguably 
represented the last gasp of socialist modernity's challenges to the capitalist dominant. Feminist challenges probably succeeded because modernity was already becoming postmodernity, with its attendent transnational capitalism, insistence of the market, globalization, computerization, the end of coloniality and the increase in diasporic communities. The start of the cyber-age through imaging technologies, the internet, the worldwide web, and yet newer processes, will bring changes to feminisms, the extent of which are not yet known. Impacts of postmodernism on gender, race, and class-on what we knew as liberal political traditions-are also not yet known. In a sense, feminists have moved from the social politics of modernism to a crisis in political activism itself. What can activism mean in a world where larger oppositional formations are no there to longer support the local levels of resistance?

Feminists must continue such local resistances-indeed, they become more vital than ever. But we must also seek ways to forge links across local actions. Finally, the impact of global finance and the cyber-age on the university is as yet unclear, although feminists certainly know that the university is under severe attack and will change drastically in the very near future.

\section{Performing Generations}

None of the women at the "Feminism Beside Itself" Conference who were of the same cultural or numerical generation necessarily thought alike or shared paradigms. But still my use of postmodern or Queer theory differs from the way it would be used by a 28 year old. For I have been arguing that the having-done-thisness of women who have been involved in various phases and aspects of feminisms for 30 years is a different place to speak from than that of a 28 year-old. The residue of the experiences remains and is never totally written over.

But why do some 28 year-olds (like Rene Denfield, discussed below) actually see the problem in terms of generation? What is at stake for them in using this word? Does the personal framing of the term "generation" in this case point to differences between a politics of the free individual subject, and a politics of how institutions and historical periods construct certain subjectpositions? How much is the debate really between academic feminisms and other career women who feel excluded from academic discourse and academic debates? 
As a partial answer, let me note that first and second wave feminists (at least in my mapping) have both the personal/longitudinal (age) axis and the generational one. Young women largely just have the latter. It is less confusing for them, since they have not had the experience of passing-through-ness that I've alluded to. Things appear as simply generational: we had the 60s, they didn't; they have raced, queered, scienced and cyborged theory, we didn't. The anxieties, therefore, have to be different.

\section{Part II: Feminisms in the Public Sphere and the Academy}

I want to distinguish two different sites where generational feminist debates are taking place. First, there are debates ongoing in the public media sphere (popular books, book reviews, television news and talk shows, journalism); and second, there are debates within the academy, where I am. [ 1 ] These latter need to be further distinguished as dealing with anxieties about feminist content or perspectives and anxieties about institutional structures. Many people are familiar with the main lines of these debates, so I will be brief.

\section{Feminist Generational Anxieties Outside the Academy}

There's no doubt that the US is experiencing a continuing backlash against "feminism" in the public cultural terrain. My quotation marks around "feminism" indicate that what is being attacked from outside the academy is clearly a fantasy of a feminist monolith, a set of myths and images that backlashers take for "true." Witness the review of yet another anti- "feminism" book in The New York Times Sunday March 19, 1995, this time by Rene Denfeld, who moves in on Katie Roiphe's coattails and calls feminists the "new victorians." What's interesting is that the reviewer, Michelle Green of People Magazine, situates the book confidently within a generational discourse: her first line notes that Denfeld is 28 years old and a "bold writer" who "fueled by good sense and righteous anger... has taken on the feminist 
establishment in a book sure to provoke her radical foremothers." Like others of her generation, the reviewer continues, "she is impatient with the women's movement and appalled by extremists who neglect reallife issues in favor of bashing men, worshiping the Goddess, battling porn-mongers and denouncing heterosexuality...." The reviewer concludes that like Naomi Wolf, Denfeld is weary of women being cast as "maidens in distress." They want reforms and social change that will put women on an equal footing with men," and the reviewer says "that will not happen until her generation reclaims feminism."

Something is seriously wrong when such stale views, such worn statements, are taken as valid by the editors of The New York Times Book Review. The list of accusations describes no feminist communities I know today, if they ever existed (and if they did, it would have been between 1965 and 1970-something that gives this new discourse such a curious archaic feel). I am appalled by an implicit ageist ideology that the term "foremothers" connotes: the term relegates first and second generation feminists to some fixed past place, where they are frozen in their texts. In reality, most first and second wave feminists are still growing, developing their ideas, and using their knowledge to understand changes taking place today.[ $\underline{2}$ ] Such women continue to contribute newly to feminisms. I am arguing only for their speaking position being different from younger feminists, not for their inability to develop new ideas or their being necessarily locked into prior frameworks developed during different historical moments. Further, what Denfeld argues "her generation" wants sounds very like something most of my friends want. Certainly women I know inside and outside the academy are actively pushing for abortion rights and child care.

What does it mean, then, that such stale fictions of generational splits continue to proliferate in the highculture sphere that The New York Times represents? What are the anxieties underlying the construction of such generational polarities? What ends does this old discourse serve?

One end (and an anxiety) is an attack on lesbian feminism. The fact that lesbian women are finally getting some of their needs and rights articulated is making many women anxious. The backlash seems to be primarily against lesbians, and lesbians, for some reason, are associated with "feminist foremothers," as if all "foremothers" were lesbians. This is strange, since 
while there certainly were activist feminist lesbian foremothers (e.g. Andrea Dworkin), many of the most public of early feminists (Gloria Steinem, Betty Friedan) were clearly heterosexual. And it is many of the younger women, like Catherine McKinnon (perhaps the most public of lesbian legal activists) and Kimberly Crenshaw who are dominant in the public sphere today. Why the creation of straw women against whom to rail? Why the assumption that foremother lesbian feminists have remained unchanged by all that has happened since 1960 ? Lesbianism is evidently still something that scares some straight women, although I do not fully understand the deep underlying causes for this reaction. Many glib psychoanalytic answers come to mind, but these are not sufficient.

A second end is that railing against "foremothers" hides a difference I noted earlier: namely that between an ideology of free individuals who can bring about change for their personal fulfillment; and an ideology that links women's oppressions to larger thought-systems and capitalist economic determinism. We are dealing with an attack on socialist or oppositional feminists. Barbara Johnson was probably right when she noted that what women like Roiphe and Hoff Sommers see as "feminist" is the liberation of the individual woman, subject of agency. Neither see feminism as a systematic critique of institutions; indeed, they consider the critique of systems itself as limiting women's possibilities. That is, if you start out with a concept of the "free female subject," a theory of institutional (or, I would add, psychoanalytic) constraints seems like something that is limiting. The critique of patriarchy by some feminists appears to construct victims, passivity, instead of being seen as explaining and accounting for certain observable feminine constructs. Roiphe and Hoff Sommers do not see that claiming victimhood can be empowering, as Johnson suggests it can be.[ $\underline{\mathbf{3}}$ ]

This theoretical gulf seems unbridgeable. It's improbable that an understanding between the groups can be reached. What the debates highlight is how most generalizations about any monolithic "feminism" are bound to be made from a very specific location, cultural/ intellectual context, and historical moment-none of which are articulated in books by people like Roiphe, Hoff Sommers, and Denfeld or by reviewers like Michelle Green, who lack any awareness of what shapes their perspectives. Meanwhile, many of us within the academy have painfully had to become aware of the blinders on our perspectives and to recognize that our perspectives have performative aspects that we need to develop. 
A second painful example of this backlash outside the academy is William Buckley's November 1994 Firing Line program. The thesis to be debated was "That the Women's Movement Has been Disastrous" and women from different generations and political positions were deliberately invited. The women defending the thesis (Arlene Huffington was one) came across as glamourous (given prevailing norms and social codes) while those opposing it were less obviously so. And the ensuing debates provided one with the spectator sport of angry women throwing insults back and forth. Since little clarity emerged from the highly charged language, spectators may have been left to take sides on the flimsy ground of superficial televisual appearance.

In all of these four examples, what emerges is that backlashers have confused three different areas of feminism: namely, Feminism as Personal Growth (gaining independence, autonomy, sexual and intellectual selffulfillment); Feminism as Political Activism (to change laws and policies affecting women); Feminism as Scholarship (developing new interdisciplinary insights through taking up female perspectives and topics). This confusion underlies much of the impetus of the backlash. The backlashers do not clearly distinguish the three separate but equal feminist terrains outlined.

It is true that first generation feminists did have slogans like "the personal is political," and did strive to link activism and the classroom. Such linking made sense at the time (1960s-70s), when many of the people engaged in activist movements were also dramatically altering their personal lives and were pioneering feminist scholarship and teaching. Since the same women were involved in all three feminist projects, it made sense to make up a slogan that described their intricate links.

Today's public feminists are not part of the political movements that shaped 60s-70s feminisms. They did not experience the ways in which institutions limited women's possibilities, because first and second wave feminists have opened society up and created awareness of ways in which women were marginalized and debased. 70s feminist movements have produced a situation such that younger women no longer experience so strongly the constraints that gave rise to theories that emerged from activism. Here is where Age matters: Today's public feminists focus on personal growth and individual achievement, and this masks the larger forces that still oppress the lives of many less fortunate women. Young white middle- class women were not around when such 
oppressions were painfully in place for their group. They attack academic feminists, because they do not understand how theory or scholarship works. They want a certain kind of activism-one that serves their personal, individual needs (abortion reform; child care), because they do not have any larger institutional or political theory. They do not see a need to think about other communities of women or to work for needs other than those of their own group.

\section{Summary of Generational Anxieties about the Content of Academic Feminisms}

\section{a) Anxieties of second wave academic feminists:}

Worries include the idea of being left behind, of their day being over, of having had a central role and now being shelved as a "classic."[ $\underline{\mathbf{4}}$ ] Many in this generation are located as "pioneers" by younger academic feminists but are no longer seen as forging new terrain. The paradigms the second wave used are being critiqued, but younger feminists tend to freeze the women within these texts in an ageist move. In parallel fashion, second wave feminists' concerns may be mixed unconsciously with anxieties about aging. Scholars may unconsciously succumb to the notion that it is time to "make room" for younger feminists in the academy. In this, they may participate in what Betty Friedan has called "the dominant view of age as decline" (Friedan, 1993:26).

Anxiety on the part of older academic feminists takes the form of believing that the new areas of study being opened up within feminism, like Queer Theory or Ethnic Studies, are not ones they can participate in. That theory is being "Queered" and increasingly replacing "French" literary feminism, was noted by Barbara Johnson.[ $\underline{\mathbf{5}}$ ] Within film studies, debates have taken a distinctly generational form in the challenges to 70s feminist paradigms developed around the journal Screen and the Paris Cinematheque. New interdisciplinary feminist research on science, technology and cyberspace represents another academic area in which women in the earlier "waves" were not trained.

Especially pertinent here is the impact of new theories of gender identity (like those of Donna Haraway or Judith Butler), because they appear to render dangerous the clinging onto a specifically feminine category. More 
radical than the concept of "plural feminist histories" which some have advanced (See Stanford Friedman: Elam/Weigman, 1995:42), Haraway's wake-up call to socialist feminists in her 1985 "Manifesto for Cyborgs" initiated new attention to a postulated "posthuman" body. If past feminisms have relied on the a category of "woman" as their main claim to methodological distinctiveness, we find ourselves at a new juncture-even at a crisis in our studies, when such a move is made.[ $\underline{\mathbf{6}}$ ] What is often ignored is the close link between these apparently subjective anxieties and larger changes going on in the academy-an issue that I will return to shortly.

\section{b) Anxieties of 28 year olds plus within the academy:}

For younger women, anxieties arise in competing with senior women scholars, as Jane Gallop and her student affirm in a dialogue.[ $\mathbf{7}$ ] While such women have learned from their feminist mentors, they also need to go beyond them, and this can provoke anxiety. Sometimes, there is anxiety because younger women's scholarship is not supported by an activist past, such as that which many of their mentors engaged in and which grounded the personal/political changes they were pioneering. The professionalization of Women's Studies has meant that links with activism have slackened for white women. Minority group feminists may have anxieties through the opposite problem-namely having an oppositional group to identify with outside the academy and being alarmed by the gap between this group and white feminists within the university. They may be alarmed also by the enduring whiteness of much feminist discourse they encounter within the university.

\section{Anxieties about the Structures of Feminisms, and about the Disciplines within which Feminisms Grew in the 60s and $70 s$}

As I noted earlier, the anxieties briefly outlined are closely linked with broad changes within the academy. For instance, at my institution, efforts to initiate a Cultural Studies Ph.D. program were viewed-not entirely wrongly-as endangering Women's Studies. While I would hope that any Cultural Studies program would be heavily committed to gender studies, the kind of concentrated research on women's issues clearly would not be viable within Cultural Studies. In the best of all worlds, with no limits on resources, Cultural Studies would work closely 
with other interdisciplinary programs, like Women's Studies. Then there is the question of whether Lesbian/ Gay Studies should be constituted as a separate entity from Women's Studies. To what extent do Lesbian/Gay Studies compete with Women's Studies?

As the university itself comes under attack, and as political forces having little to do directly with feminisms are changing the university, demanding that it become economically self-sufficient in many cases, so faculty are being forced to rethink disciplinary organization not primarily from the point of view of what the best organization of knowledge would be. But from the point of view of downsizing and efficiency. We face demands for cutting out administrators, eliminating course release, and doing away with graduate and other assistants. This could be turned to the benefit of Women's Studies, but it could also result in pressures to link Women's Studies with other new studies, like Cultural Studies, Media Studies, Latin American and Caribbean Studies, to which, of course, Women's Studies is often relevant.

There is the further issue of the degree to which specifically marked focus on women/gender is necessary. For example, in Film Studies, feminist perspectives were so powerful in the 80 s that they now permeate almost all the work, as increasingly does the category of race. Does this mean that flagging specifically feminist perspectives is no longer necessary? Or are such moves attempts at coopting Women's Studies and "taming" feminisms into something else? Is there any validity to notions that feminism accomplished a paradigm shift such that from now on the category "woman" has entered all scholarly domains as an available topic for research? Is the paradigm shift over, as Kuhn would argue, precisely because administrations are beginning to question what the paradigm has yet to contribute?

\section{Part III: Changing Paradigms in the Academy, Widening Gaps between Civil Society and the Academy}

The impact of the changes women brought about in all three feminist terrains noted above-politics and society, 
personal life, scholarship-has in turn altered the viability of all three being so intricately linked. Meanwhile, as noted, other things have changed around and along with feminism, one of which is the widening gap between feminist activism and feminist scholarship, to which I now turn.

The impact on feminism of the widening gap between civil society and the academy is a different kind of problem than that of age or generation. It has to do with what kind of feminist research one wants to, or can, undertake within the university: Do women see their research as closer to activism and women's social oppressions? As closer to the level of abstract theory? Or do they see the distinction as invalid, and part of the problem? But this widening gap also has to do with the changing nature of the university in a period when both state and the federal governments are increasingly reluctant to fund university research.

The question of what feminist research should be done is a different category of difference than that of age or generation. And it would be a mistake to try to align age with a specific sort of research interest, despite the fact that older women have come along the route from modernism to postmodernism to the cyber-age. Some scholars keep on changing their paradigms as things change around them; others keep to paradigms they are familiar with and with which they have worked for many years.

Yet, as I argued at the start, those of us who grew up inside modernist political, intellectual, and academic contours are very differently situated than those who grew up when postmodernism was already a transitional period between modernism and the cyber-age. I'm not sure that there can be a real dialogue amongst what may amount to three differently contexted "generations" or, if you will, feminist groups. The questions and issues that interest scholars coming to their work at different historical moments will be different. The very questions, for example, that a scholar like Joan Scott asks arise out of moving from a modernist to a postmodernist feminism. They may not arise for the 28 year old graduate student or young professor. Meanwhile, the queering of theory is likely to attract scholars who never grew up intellectually through psychoanalysis. It is perhaps in this strange sense that age does implicate research topics.

One of the challenges that faces us is how to develop new resistance strategies along with new activist 
paradigms. The strategies have to be collaborative. And for that, we need fully to understand our political and theoretical differences. However, do we also need to find new language to describe ourselves, given the disrepute public women attacking us have managed to plunge feminism into "out there"? In this particular historical moment, facing as we do in New York State drastic budget cuts, feminists will need more collaboration and political alliances than ever before. Reorganization is being undertaken not for what is best for producing knowledge but for what's most cost effective and efficient.

The futures of feminisms-and feminisms in the future-will depend on three main challenges:

1) on how those of us inside the academy will be able increasingly to negotiate the gap between "inside" and "outside" the academy. How can academic feminists intervene in the right wing attacks on a fiction of feminisms that women writing popular books outside the academy have invented? How can we insert our own competing discourse-not to convince the public feminists (they cannot be convinced) but to reach teachers in high schools and in our classes-so that feminism might have a future?

2) Futures of feminisms will depend on how far academic feminists are able to have a say in the demand for reorganization, downsizing, and efficiency that most State Universities are already facing and will increasingly face. It will be important for us to articulate what our contributions to knowledge continue to be and what we need for our teaching and scholarship.

3) Third (but not finally-I am sure there are many more things)-American feminists need to link up with feminists globally. Given postcoloniality, postmodernism, and the cyber-age, women are all, of course, already linked economically through global corporations and market strategies that use our bodies in similar ways. The production and poliferation of cyberspace and computer technologies is rapid, and feminists need to keep on top of technologies. Phillippine women processing an 18thcentury novel so that we can have a machine readable text is already a reality. Western feminists are implicated in this new form of colonialism, and they must plan strategies around their complicity.

Yet while the public sphere ridicules feminists who take cyberspace literally, [ $\underline{\mathbf{8}}$ ] American feminists of all ages and in all disciplines need to develop cyberspace skills. 
As opposed to the victim narratives about the internet, my experience shows the tremendous tool it can be for crucial cross-national links amongst women situated at great geographical distances.[ $\underline{\mathbf{9}}$ ] Meanwhile, research on the impacts of the cyber-age on feminisms, on our understanding of the female body and on our still heavily modernist theorizing, is urgent. This is not a matter of succumbing to Baudrillardean seductions, or of displacing activist politics with cultural politics (as Elizabeth Weed, in her conference presentation, feared), but of including in our cultural work analyses of women's fascination with what the market produces. The challenge is to understand the interaction among new technologies, economic pressures for constantly increased consumerism, women's oppressions, and feminist analyses. We will need to be alert as we develop feminisms for the future.

\section{NOTES}

1. This is not to deny other locations for these debatessuch as within activist feminist spheres-but I can only address briefly the two sites of academic feminism and the public-sphere discourses in this essay.

2. See Betty Friedan's The Fountain of Age (New York: Simon and Schuster, 1993) for evidence both of ageist assumptions in American culture generally, and for an example of a first wave feminist still growing and changing as she advocates our developing a new concept of aging.

3. Mentioned in a paper on feminism at the Modern Language Association in San Diego, December 291995.

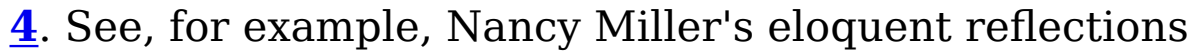
on her coming into feminism in Getting Personal: Feminist Occasions and Other Autobiographical Acts (Routledge: New York and London, 1991).

$\underline{5}$. These comments were made in the same MLA paper noted above.

6. See Susan Friedman Stanford, Feminism Beside Itself.

7. This dialogue will be published in a volume on

Feminist Generations being edited by E. Ann Kaplan and Devoney Looser. 
8. I am thinking of the ridicule a young professor at Birmingham University received in the British Times for titling herself a "cyber-feminist." In Australia, there is evidently a group call the "VNS Matrix: A Cyberfeminist Collective."

9. I am thinking particularly of relationships I have developed and then been able to increase with Japanese women through the internet. The co-ordinator at Yokohama Women's Forum and I organized my lecture at Yokohama this July through internet contact. Meanwhile, the co-ordinator worked via email to bring women from different areas in Japan to the lecture. This same coordinator will be the main networking person at the Beijing Women's meeting in August 1995, and will keep me up to date daily with what is going on there.

Accueil Surfaces | Table des matières | Recherche $\underline{\text { Surfaces Home Page | Table of Contents | Search }}$

PUM | Livres | Revues | Publications électroniques | Vente et distribution 